\title{
A STUDY OF PSYCHIATRIC MORBIDITY IN ADOLESCENT SUICIDE ATTEMPTS
}

\author{
M. Arun Venkatesh ${ }^{1}$ \\ ${ }^{1}$ Assistant Professor, Department of Psychiatry, Government Sivagangai Medical College, Tamilnadu.
}

\begin{tabular}{l}
\hline ABSTRACT \\
AdCKGROUND \\
neurochemt suicide is of burning health concern. It is the third commonest cause of death in India. Neuroanatomical and \\
psychosocial factors in those who attempt suicide.
\end{tabular}

\section{MATERIALS AND METHODS}

A cross-sectional survey study with sample size 50. Patients who come to Psychiatry department for suicide prevention counselling are screened for psychiatric illness as well as substance use, family history of suicide, personality, conduct disorders as well as psychosocial factors are studied.

\section{RESULTS}

The results are formulated in tables with carefully evaluating psychiatric morbidity by using ICD-10 criteria. Suicide rating scales are used to assess the suicide intent and hopelessness is the main factor contributing to adolescent suicide attempt who are psychiatrically ill.

\section{CONCLUSION}

Adjustment disorder and depression plays a major role in psychiatrically ill suicide attempters. Interpersonal conflicts play a major role in non-morbid adolescents.

\section{KEYWORDS}

Adolescent Suicide Attempts- Psychiatric Morbidity- Psychosocial Factors.

HOW TO CITE THIS ARTICLE: Venkatesh MA. A study of psychiatric morbidity in adolescent suicide attempts. J. Evolution Med. Dent. Sci. 2018;7(05):564-566, DOI: 10.14260/jemds/2018/128

\section{BACKGROUND}

Adolescent suicide is the third leading cause of death in the 15 - 24 year olds, according to centre for disease control and prevention. ${ }^{1}$ A study by NIMH showed the ratio of attempted:completed suicide is 25:1. Risk factors for attempted suicide in youths are depression, substance use, aggressive or disruptive behaviour. WHO estimates about 170,000 deaths by suicide in India every year. The surveyed deaths in 15 years or older who die due to suicide is 26.3 for men and 17.9 for women. Men had a high risk of $1.7 \%$ than women $1 \%$. With high risk in South India, 3.5\% in men and $1.8 \%$ in women. $50 \%$ deaths are due to poisoning, mainly with pesticides.

\begin{abstract}
Aims
To study the Psychiatric morbidity in adolescent suicide attempts and to assess the severity of suicide intent and stressful life events, hopelessness, suicide severity rating and self-esteem, and comparing those among psychiatrically morbid and non-morbid adolescents.
\end{abstract}

\section{Objectives}

1. To study the Psychiatric morbidity in adolescent suicide attempters.

'Financial or Other Competing Interest': None.

Submission 22-12-2017, Peer Review 14-01-2018,

Acceptance 22-01-2018, Published 29-01-2018.

Corresponding Author:

Dr. M. Arun Venkatesh,

Plot No. 2, Subramania Siva Street,

Nehru Nagar, Madurai-10.

E-mail: arunvenkat1973@gmail.com

DOI: $10.14260 /$ jemds $/ 2018 / 128$

\section{(c) $(1)(5)$}

2. To grade the suicide intent and stressful life events and comparing it among those with psychiatric illness and those without illness.

3. To assess hopelessness and grade, and comparing it among morbid group in adolescent suicide attempts.

4. To assess suicide severity and self-esteem and grading it and comparing it with morbid and non-morbid groups.

\section{Tools Used}

1. Semi-structured proforma to collect socio-demographic data, family history of mental illness, substance use, family h/o mental illness, associated with alcohol use etc.

2. MINI schedule for assessing Psychiatric morbidity.

3. Suicide intent measured by Beck suicide intent scale, mean stress scoring by presumptive stressful life events scale by Gurmeet Singh, hopelessness by Beck hopelessness scale.

4. Severity of suicide attempt is measured by Columbia suicide severity rating scale and self-esteem by Rosenberg Self-Esteem scale.

\section{Review of Literature}

Suicide is a conscious act of self-induced annihilation, best identified as a multi-dimensional malaise in a needful individual, who defines an issue for which suicide is perceived as the best solution. This definition is given by Schneidman $^{2}$ who is the Father of Suicidology. Suicide attempt is a life-threatening act requiring medical attention that is committed with a conscious intent to end one's life. Suicide counters- Those factors that inhibit the suicidogenic tendencies are called suicide counters, can be economic, religious, moral, ethical or social. In World scenario, 4 lakh people commit suicide every year around the world. In some 
countries like India, it is the top three causes of death for people between 15 and 34 years. A study by NAHIC (National adolescent health information centre) told suicide accounts for $11.2 \%$. The suicide rates by age from ages $10-24$ increased dramatically between early adolescence and young adulthood. In the 10 - 14 years' age group, it is $1.2 \%$ in the 15- 19 years' age group. It accounts for $7.3 \%$. The first person to look at suicide from a truly psychological point of view was Sigmund Freud, 3 who wrote Eros vs. Thanatos. Life is a constant battle between these two instincts. In the suicidal, it is obviously the death instinct predominates. Rates per year as high as 1 suicide per 1000 population are seen in Falkland Islands and 1 suicide per 1500 population in Hungary. The social motives of suicide is given by Durkheim, ${ }^{4}$ founder of Empirical Research in Sociology and Suicidology with the level of social integration as the opposite of anomia, isolation and egoism. Adolescents who had been physically or sexually abused were significantly more likely to experience suicidal thoughts and behaviour. Obsession with death is a warning signal, ex. drawing of a will, writing own eulogy, talking about the reactions of various people or their death, dramatic changes in personality or appearance. Indian studies on adolescent suicide.

\section{Suicides}

A NIMHANS Study in 2007 showed 1,22,637 persons ended their life by suicide, the ratio of attempted:completed suicide being 8-10:1. The national average is $10.8 / 1,00,000$ with top in Bengaluru- 42.7 and Chennai- 36 . House is the commonest place of suicide attempt and hanging is the most frequently used method for completed suicide (61\%), while poison is the commonest method of attempted suicide (87\%), burns $12 \%$ in completed and $6 \%$ of attempted suicide. $30 \%-40 \%$ of the suicides linked to the direct or indirect effects of alcohol > low education, low socio-economic status proved to be the more vulnerable factors in youth suicide. Commonest method of suicide is poisoning 5 - 91\% of which Aluminium phosphide- 33\%, Organophosphorus compound- 24\%, others- 34\%. Psychiatric morbidity- 57\%, of which Mood disorders- 75\%, Adjustment disorder-15\%, Substance use disorders- $3 \%$, Schizophrenia- $3 \%$ and Personality disorders $1 \%$.

\section{Neurochemistry}

Dorsal raphe nucleus synthesise serotonin. In completed suicide, there is reduced 5-HT transporter binding ${ }^{6}$ in the prefrontal cortex. Increased cortisol is found in suicide attempters of the depressed by Meltzer et $\mathrm{al}^{7}$ using the probe 5-HT. Reduced Prolactin ${ }^{8}$ in suicide attempters of high lethality were found in for studies using Clomipramine or dfenfluramine. Low CSF 5-hydroxyindoleacetic acid (AsbergM ${ }^{9}$ et al), metabolite of serotonin has been associated with impulsive aggression and suicidal behaviour. The most consistent abnormality observed in depressive disorders is increased frequency of abnormal hyperintensities in subcortical regions such as periventricular regions, the basal ganglia and the thalamus. The most widely replicated PET finding in depression is decreased anterior brain metabolism, more pronounced on the left side.

Types of suicide4- Egoistic- occurs in individual with high isolation, individuation. Altruistic- Due to insufficient individuation. Seen in individuals excessively integrated to society or group. Anomic experiences violent accusations and counter accusations between self and significant others. Fatalistic- Rules and regulations excessively regulate the individual, seen in prison communities.

\section{MATERIALS AND METHODS Study Design}

Cross-sectional study.

The sample size was decided for convenience and the sampling method adopted was consecutive sampling. This study was carried out in the outpatient services of the Department of Psychiatry, between Mar - Aug 2012 Tirunelveli Medical College Hospital. The study was approved by the Institutional Ethical Committee of Tirunelveli Medical College. A formal written consent in Tamil was obtained from all participants included in the study. 'All participating patients who are sent for suicide prevention counselling to OP were given information sheet pertaining to the nature of the study.

1. Semi-structured proforma to collect socio-demographic data, Family History of mental illness and substance use, Substance abuse in adolescent patients, History of medical illness, Family history of suicidal attempt, Previous history of suicidal attempt, Help or advise sought before attempt.

2. Suicide intent was measured by Beck's suicide intent scale.

3. Mean stress scoring of stressful life events was measured by presumptive stressful life events scale (PSLES) developed by Gurmeet Singh et al (PSLES).

4. Hopelessness is measured by Beck hopelessness scale1974.

5. Self-esteem in adolescents is measured by Rosenberg Self-esteem scale and suicide severity by C-SSRS.

\section{Statistical Design}

The SPSS version is 13.0 and chi-square tests were used to analyse the data.

\section{RESULTS}

\begin{tabular}{|c|c|c|c|c|}
\hline Sl. No. & \multicolumn{2}{|c|}{ Variable } & $\mathbf{N}$ & $\%$ \\
\hline \multirow{2}{*}{1} & \multirow{2}{*}{ Age (yrs.) } & $13-16$ & 13 & 26 \\
\hline & & $17-19$ & 37 & 74 \\
\hline \multirow{2}{*}{2} & \multirow{2}{*}{ Sex } & Male & 18 & 36 \\
\hline & & Female & 32 & 64 \\
\hline \multirow{3}{*}{3} & \multirow{3}{*}{ Education } & Illiterate & 3 & 6 \\
\hline & & Primary & 10 & 20 \\
\hline & & Secondary & 37 & 74 \\
\hline \multirow{3}{*}{4} & \multirow{3}{*}{ Occupation } & Student & 25 & 50 \\
\hline & & Semi-skilled & 20 & 40 \\
\hline & & Skilled & 5 & 10 \\
\hline \multirow{3}{*}{5} & \multirow{3}{*}{ SES } & Low & 21 & 42 \\
\hline & & Middle & 21 & 42 \\
\hline & & High & 8 & 16 \\
\hline \multirow{2}{*}{6} & \multirow{2}{*}{$\begin{array}{l}\text { Marital } \\
\text { Status }\end{array}$} & Single & 42 & 84 \\
\hline & & Married & 8 & 16 \\
\hline \multirow{2}{*}{7} & \multirow{2}{*}{$\begin{array}{l}\text { Family } \\
\text { Type }\end{array}$} & Nuclear & 39 & 78 \\
\hline & & Joint & 11 & 22 \\
\hline \multirow{2}{*}{8} & \multirow[t]{2}{*}{ Domicile } & Rural & 38 & 76 \\
\hline & & Urban & 12 & 24 \\
\hline & & $\begin{array}{c}\text { rameters o } \\
\text { Profile }\end{array}$ & & ohic \\
\hline
\end{tabular}




\begin{tabular}{|c|c|c|c|}
\hline Sl. No. & Type of Psychiatric Morbidity & (n= 21) & $\%$ \\
\hline 1 & $\begin{array}{c}\text { Adjustment } \\
\text { Disorder }\end{array}$ & 9 & $43 \%$ \\
\hline 2 & Depression & 8 & $38 \%$ \\
\hline 3 & ADS & 1 & $4.7 \%$ \\
\hline 4 & Schizophrenia & 1 & $4.7 \%$ \\
\hline 5 & Conduct Disorder & 2 & $9.4 \%$ \\
\hline \multicolumn{2}{|c|}{ Table 2. Table showing Type of Psychiatric Illness } \\
\hline
\end{tabular}

\begin{tabular}{|c|c|c|c|}
\hline Sl. No. & Variable & $\begin{array}{l}\text { Psychiatric } \\
\text { Morbidity } \\
\text { Yes/No }\end{array}$ & $\begin{array}{c}\text { Statistics } \\
\text { Chi-Square Test }\end{array}$ \\
\hline 1. SIS & $\begin{array}{l}<13 \text { yrs. } \\
>13 \text { yrs. }\end{array}$ & & $\begin{array}{c}\mathrm{X} 2=12.04^{* *} \\
\mathrm{P}<0.001\end{array}$ \\
\hline 2. PSLES & $\begin{array}{l}<100 \\
>100\end{array}$ & $\begin{array}{c}1026 \\
113\end{array}$ & $\begin{array}{c}\mathrm{X} 2=10.673^{*} \\
\mathrm{P}<0.05\end{array}$ \\
\hline $\begin{array}{l}\text { 3. Family H/O } \\
\text { Mental Illness }\end{array}$ & $\begin{array}{l}\text { Yes } \\
\text { No }\end{array}$ & $\begin{array}{l}134 \\
825\end{array}$ & $\begin{array}{c}\mathrm{X} 2=12.553^{* *} \\
\mathrm{P}<0.001\end{array}$ \\
\hline $\begin{array}{l}\text { 4. H/O Other } \\
\text { Substance Use } \\
\text { (Cannabis, } \\
\text { Solvent) }\end{array}$ & $\begin{array}{l}\text { Yes } \\
\text { No }\end{array}$ & $\begin{array}{c}74 \\
1425\end{array}$ & $X 2=2.708$ \\
\hline $\begin{array}{l}\text { 5. Family H/O } \\
\text { Attempted } \\
\text { Suicide }\end{array}$ & $\begin{array}{l}\text { Yes } \\
\text { No }\end{array}$ & $\begin{array}{c}64 \\
1525\end{array}$ & $X 2=1.66$ \\
\hline $\begin{array}{l}\text { Associated } \\
\text { with Alcohol } \\
\text { Use }\end{array}$ & $\begin{array}{l}\text { Yes } \\
\text { No }\end{array}$ & $\begin{array}{c}87 \\
1322\end{array}$ & $28^{X 2=1.1}$ \\
\hline \multicolumn{4}{|c|}{$\begin{array}{c}\text { Table 3. Showing Comparison of Parameters Used in the } \\
\text { Study and Rating Scales among Psychiatrically } \\
\text { Morbid and Non-Morbid }\end{array}$} \\
\hline
\end{tabular}

\begin{tabular}{|c|c|c|c|}
\hline $\begin{array}{l}\text { Sl. No. and } \\
\text { Variable }\end{array}$ & Severity & \begin{tabular}{|c|} 
Psychiatric \\
Morbidity Yes/No
\end{tabular} & Chi-Square \\
\hline BHS & $\begin{array}{c}\text { Mild } \\
\text { Severe }\end{array}$ & \begin{tabular}{|c|}
1022 \\
117 \\
\end{tabular} & $\begin{aligned} & \mathrm{X} 2=4.214^{*} \\
& \mathrm{P}<0.05\end{aligned}$ \\
\hline C-SSRS & $\begin{array}{c}\text { Mild } \\
\text { Severe }\end{array}$ & $\begin{array}{c}1324 \\
85\end{array}$ & $X 2=2.747$ \\
\hline RSE-S & $\begin{array}{c}\text { Low } \\
\text { Adequate }\end{array}$ & $\begin{array}{l}121 \\
928\end{array}$ & $\begin{array}{c}\mathrm{X} 2=18.247^{* *} \\
\mathrm{P}<0.001\end{array}$ \\
\hline
\end{tabular}

Table 4. Showing Comparison of Suicide Rating Scales and Psychiatric Morbidity

\section{DISCUSSION}

Suicide attempts are common in female adolescents than males and the ratio of female-to-male attempts is 3: 1 and males are more common completers of suicide in the ratio of 3:1 as seen in studies by NASO shift project and suicide study by NIMHANS. In our study there are more females (32) vs. males (18), making a ratio of 1.8: 1 in agreement to studies of teen suicide and study by KE Sadanandan Unni which showed females are 3 times more common suicide attempters than males. Suicidal attempts are common in rural population (38) vs. urban (12) with rural population. Our study showed statistical significance and strong correlation and agreement with this notion. The low and high intent group when compared among psychiatrically ill and non-ill showed X2- value of 12.04 and $p$-value $<0.001$ and this is found to be statistically highly significant. In our study there is statistical correlation between substance use among adolescents, but not their family members, associated with correlation of alcohol use during the attempt. Also, correlation for family history of mental illness and comparing groups that is among ill and non-ill, which showed those with family history of mental illness like depression are more prone to suicide. The $\mathrm{X} 2$ value being 12.553 ( $\mathrm{p}<0.001$ ) and statistically highly significant. Our study too shows strong correlation between stressful life events $(X 2=10.673)$ among psychiatrically ill and non-ill groups, but alcohol use during the attempt and other substance use in comparable groups showed no significant values.

Our study showing comparison of suicide rating scales like BHS and RSE-S shows strong correlation, but no correlation with C-SSRS among psychiatrically morbid and non-morbid.

\section{CONCLUSION}

Adjustment disorder and depression plays a major role in psychiatrically ill suicide attempters. Interpersonal conflict plays a major role in non-morbid adolescents.

\section{REFERENCES}

[1] Moskos M, Achilles J, Gray D. Adolescent suicide myths in the United States. Crisis: The Journal of Crisis Intervention and Suicide Prevention 2004;25(4):176-82.

[2] Vyas JN, Ahuja N. Textbook of postgraduate psychiatry. New Delhi, Jaypee publishers, 1999:pp 528.

[3] Freud S. Mourning and melancholia. In Strachey J. (Ed and Transl), The standard edition of the complete psychological works of Sigmund Freud. London Hogarth Press and the institute for psychoanalysis original work published, 1917;14:237-58.

[4] Vyas JN, Ahuja N. Textbook of postgraduate psychiatry. New Delhi Jaypee publisher, 1999:pp 529-30.

[5] Vyas JN, Ahuja N. Textbook of postgraduate psychiatry. New Delhi, Jaypee publisher, 1999:pp 533.

[6] Coccaro EF, Siever LJ, Klar HM, et al. Serotonergic studies in patients with affective and personality disorders. Correlates with suicidal and impressive aggressive behaviour. Arch Gen Psychiatry 1989;46(7):587-99.

[7] Meltzer HY, Perline R, Tricou BJ, et al. Effects of 5 hydroxytryptophan on serum cortisol levels in major affective disorders. II. Relation to suicide, psychosis, and depressive symptoms. Arch Gen Psychiatry 1984;41(4):379-87.

[8] Arango V, Underwood MD, Mann JJ. Biologic alteration in the brainstem of suicides. Psychiatr Clin North Am 1997;20(3):581-93.

[9] Asberg M, Traskman L, Thoren P. 5-HIAA in the cerebrospinal fluid: a biochemical suicide predictor? Arch Gen Psychiatry 1976;33(10):1193-7. 